Proc. Estonian Acad. Sci. Biol. Ecol., 2002, 51, 4, 242-256

\title{
Pulsatilla patens and Pulsatilla pratensis (Ranunculaceae) in Estonia: distribution and ecology
}

\author{
Indrek Pilt $^{\mathrm{a}}$ and Ülle Kukk ${ }^{\mathrm{b}}$ \\ ${ }^{\text {a }}$ Institute of Botany and Ecology, University of Tartu, Lai 40, 51005 Tartu, Estonia \\ b Environmental Protection Institute, Estonian Agricultural University, Akadeemia 4, 51003 Tartu, \\ Estonia; kukk@envinst.ee
}

Received 3 April 2002, in revised form 16 May 2002

\begin{abstract}
Despite the great changes in land use, the distribution of Pulsatilla patens and P. pratensis (Ranunculaceae) in Estonia, reconstructed using herbarium specimens and notes, was quite stable throughout the 20th century. Considering the data on the present sizes and habitat conditions of $29 P$. patens and $34 P$. pratensis populations, in our estimation, around a tenth of the territory of Estonia should, at the moment, be habitable for these species. Both species prefer well-lit locations, created by some disturbance such as fire, logging, etc. The temporal deterioration of habitats through overgrowing could be buffered to some extent by the long life span of adult plants. The main threatening factor is current logging practice, which causes severe contraction of populations.
\end{abstract}

Key words: Pulsatilla patens, Pulsatilla pratensis, distribution, population size, habitats, land use.

\section{INTRODUCTION}

Species success or failure in modern floras is mainly determined by land use (Hodgson, 1986). Estonian landscapes changed greatly during the 20th century. The area of forests increased almost three-fold (from 14\% to 42\%) and the area of agricultural land decreased almost two-fold (from 65\% to 30\%) throughout the century (Mander \& Palang, 1994; Mander et al., 1994). A similar trend has been observed elsewhere in Europe (Mücher et al., 2000). The increasing fragmentation, polarization, and disturbance of Estonian landscapes have been due to the concentration of agricultural activities, land amelioration, and the oilshale industry (Mander \& Palang, 1999).

To evaluate the impact of changing land use patterns on plant species distribution, knowledge of the distribution of the species in the past is required. In 
Switzerland, for example, the old regional floras and herbarium specimens proved to be effective tools in reconstructing former distributions (Klecak et al., 1997). In Estonia, the available floristic material about the 20th century is quite extensive (Kukk, 1999), including herbarium specimens, floristic studies, and notes, which makes the reconstruction of former distribution areas possible in several cases. Complementing distribution data with the data about species ecology provides an opportunity to interpret the changes, but also to predict possible developments in the future. Different phylogenies of species complicate making generalizations about the traits that determine their success or failure under certain conditions. When information on the evolution of the group of species under consideration is scarce, it could be enough to compare pairs of congeneric species (Eriksson \& Jakobsson, 1998).

The present paper describes the ecology and distribution of two pasqueflower species, Pulsatilla patens and P. pratensis (Ranunculaceae), in Estonia. A decline in the abundance of both species has been observed in many European countries, and they are listed in several national lists of threatened plants. For instance, P. patens is classified in Finland, Latvia, and the St. Petersburg region as care demanding; in Lithuania, Poland, and Sweden, as vulnerable; and in the Mecklenburg-Vorpommern area, as extinct (Ingelög et al., 1993). P. pratensis is classified in Latvia as care demanding; in Norway and the MecklenburgVorpommern area, as vulnerable; in the St. Petersburg region and Lithuania, as rare; in Schleswig-Holstein and the Kaliningrad region, as endangered (Ingelög et al., 1993; Anon., 1992). In Estonia, P. patens is listed in the Estonian Red Data Book as care demanding (Lilleleht, 1998). Law protects both species since 1995.

The aim of the present paper is (1) to characterize the distribution of $P$. patens and $P$. pratensis in Estonia during the 20th century, (2) to describe the ecology of the species, (3) to interpret the distribution patterns, using knowledge about the biology and ecology of the species, and (4) to discuss the potential threatening factors, in order to provide recommendations for nature conservation.

\section{MATERIAL AND METHODS}

\section{Species}

P. patens and $P$. pratensis are long-lived perennials with an upright, branching rhizome, which results in clump forming by older plants. Vegetative spreading occurs only by infrequent splitting of bigger clumps (Rysina, 1981; Wildeman \& Steeves, 1982). Both species flower in spring (mid-April to end of May), P. patens about two weeks earlier. Seeds are dispersed from the end of June to the beginning of July. Although the species have traits of anemochores, dispersal distances remain short (for closely related $P$. vulgaris, rarely more than $20 \mathrm{~cm}$; Wells \& Barling, 1971). Given enough warmth and moisture, germination occurs in late summer; in unsuitable conditions it is delayed until next spring. Only a transient seed bank is formed. 
P. patens sensu lato shows widespread circumpolar distribution, growing in Europe as well as in North America (Hulten \& Fries, 1986). In Europe it (ssp. patens) is mainly confined to East Europe and reaches its northern limit of distribution at $66^{\circ}$ latitude in the regions of Arkhangel'sk and Pechora in Russia (Jalas \& Suominen, 1989). In several isolated localities, for example in Germany (Hegi, 1965-1974) and in Finland (Uotila, 1996), its populations are considered to be relicts. In Estonia the species is at its northwestern border of continuous distribution.

P. pratensis is a European endemic, growing in Eastern and Central Europe. The northernmost habitats are around $60^{\circ}$ latitude in Norway, Sweden, Estonia, and the St. Petersburg region (Jalas \& Suominen, 1989). All northernmost populations, except Estonian, are isolated from the area of continuous distribution, and should be regarded as relicts of previous more widespread distribution (e.g. Torvik et al., 1998).

\section{Distribution data}

Considering the amount and character of the available information, as well as the expected reaction time to major land use changes, we divided the distribution data into three periods. The first period, from the 19th century to 1920 , is characterized by scarcity of information, due to the small number of investigators-collectors, and by the concentration of their activity around larger towns (Tallinn, Tartu). Therefore, distribution data from that period reflect the regions where amateur botanists worked, rather than the actual distribution of Pulsatilla species. The available information is based solely on herbarium specimens, mainly kept in the herbariums of the University of Tartu and the Institute of Zoology and Botany of the Estonian Agricultural University. The oldest herbarium specimen of $P$. pratensis is dated 1846 and that of $P$. patens, 1855.

The second period, 1921-70, was the most intensive period of botanical investigations in Estonia. Before World War II, many professional as well as amateur botanists conducted extensive fieldwork. The composition of distribution maps of rare plant species began in 1932, and the mapping of Estonian vegetation, in 1934. After the war, in the 1950s, this work intensified again. Extensive fieldwork was carried out to complete the vegetation map (Laasimer, 1965) and a nine-volume book on the Estonian flora (Eesti NSV Floora, 1953-1984). Many herbarium specimens as well as floristic notes are available from that period. The greatest changes in land use in the 20th century occurred during that period (Mander \& Palang, 1999). In the 1920s, many small farmsteads were established according to the Land Reform Act of 1919, but at the end of the 1940s an opposite trend - the concentration of agriculture in the form of soviet collectivization started. Drastic changes took place in agriculture as well as in forestry practice.

The latest period, starting from 1971, is characterized by the concentration of botanical investigations on local floristic studies or on particular taxonomic groups. Considering the changes that had occurred in land use, a survey of previous distribution data, and the establishment of the current status of several 
rare plant species was started in the 1970s. Since 1994, systematic monitoring of rare and protected species is part of the State Monitoring Programme of the Estonian Environment. Data on pasqueflowers are also accumulated within the framework of this programme. Special studies on Pulsatilla species were started in 1999. As the precision of locality determination for older data is not high ("near a village" etc.), distribution maps are provided on the basis of presenceabsence in the UTM grid system, widely used as a basis of biogeographical maps (e.g. Kotiranta et al., 1998). Quadrats of $10 \times 10 \mathrm{~km}$ within the $50 \times 50 \mathrm{~km}$ quadrats are used.

\section{Population size}

As the older data are quite inconsistent, and due to problems connected with estimation (see below), population sizes are only given for populations visited by the authors between 1995 and 2001. There were 29 such populations for $P$. patens and 34 for $P$. pratensis, distributed all over Estonia (Appendix). Populations were regarded as separate when the distance between them was at least $1 \mathrm{~km}$.

Establishment of current population sizes appeared to be associated with several difficulties. First, a group of leaf rosettes, a clump, need not always comprise one genetic individual, as several seeds may disperse and establish together. As the excavation of plants or their DNA analysis are the only ways to verify this, we refer hereafter not to individuals, but to plants or clumps. Secondly, population size is not estimable on the basis of flowering plants, because only a fraction of plants flower in any one particular year. The leaves generally develop later, after flowering, and so nonflowering individuals remain unnoticed. For instance, on a $10 \times 10 \mathrm{~m}$ monitoring plot for P. patens (Vastseliina, South Estonia) there were 18 plants, 9 of them generative, on 5 May 1999. On 8 June we counted 164 plants already, although the number of flowered plants had not changed. Population size estimation based on clumps of leaves is also difficult, especially for $P$. pratensis, whose bipinnate leaves are quite unremarkable in vegetation. So, although the above-mentioned problems are considered, the established population sizes still remain only very rough estimates and are given in orders of magnitude 10, 100, 1000, and 10000 .

\section{Habitat}

Habitat data were compiled for the same set of recently visited populations as the population size data (Appendix). Forest habitats were classified into site types according to Lõhmus (1984), and the site type groups are based on the hierarchical classification scheme by Paal (1997). In the case of other vegetation types, Paal (1997) was followed. One population could inhabit locations belonging to different site types.

Light availability was estimated visually, dividing the habitats into open, halfopen, or closed (Appendix). This corresponds to no shade, partial shade, or total shade in the case of trees and bushes. 
Data on soil conditions were collected from eight sites all over Estonia where one or both species occur. Soil types were estimated on the basis of soil profiles, using the classification by Reintam (1986). Because of the varying terminology of soil classification, only the main types (rendzina, podzol etc.) are mentioned here. Roots of Pulsatilla species are mainly distributed in the upper $30 \mathrm{~cm}$ layer of soil (cf. also Rysina, 1981), but occasionally they can reach at least twice as deep (M. Öpik \& I. Pilt, pers. comm.). Soil samples were taken so that they contained a mix of upper $30 \mathrm{~cm}$ horizons (without $\mathrm{O}$ or (O) A horizon). The values of $\mathrm{pH}$ and nitrogen, phosphorous, and potassium content are means of samples taken from one profile per site. Also the humus content was analysed. Processing of samples followed Moore \& Chapman (1986). The soil $\mathrm{pH}$ was determined with a $\mathrm{pH}$ meter in a soil-water mixture (ratio 1:2.5). For the determination of nitrogen content the soil sample was digested with $\mathrm{H}_{2} \mathrm{SO}_{4}$ to convert organic $\mathrm{N}$ to $\mathrm{NH}_{4}$, which was distilled after alkalization and detected by titrimetry. The total soil organic matter was estimated by measuring the content of organic carbon. The method described is a wet-oxidation procedure using potassium dichromate with external heat and back titration to measure the amount of unreacted dichromate. Mobile forms of phosphorus and potassium were determined by the Egner-Riem-Domingo method.

\section{RESULTS}

\section{Distribution}

Two main regions of distribution could be distinguished for P. patens: East and Southeast Estonia, and North and Northwest Estonia (Fig. 1). This species is completely absent on the islands and has a very scattered distribution in West and Northeast Estonia. It disappeared from the surroundings of larger towns (Tallinn, Tartu) and from central Estonia already at the beginning of the 20th century it has not been found from 14 UTM quadrats since 1920. During the period from 1921 to 1970, P. patens occurred in 42 quadrats, and from 1971 to 2000, in 39 quadrats. Only 18 quadrats were occupied in both these periods. In general, the appearances-disappearances occur within neighbouring quadrats. However, it seems to us that this can be explained by different fieldwork description rather than seed dispersal. The earlier data are often nondescript, and there could be dislocations on the borders of two neighbouring UTM quadrats, especially in the case of localities on the edge of quadrats. No clear retreat or expansion on a regional scale is observable.

The distribution of $P$. pratensis covers the regions where $P$. patens is found, but it is also frequent throughout the whole of North Estonia, including the northern islands, and in West Estonia and the western islands (Fig. 1). Since 1920 P. pratensis has not been found in eight UTM quadrats that it previously inhabited. Of the 85 quadrats occupied from 1921 to 1970 , according to our data only 37 were still occupied after 1971. Thus, of the 72 quadrats occupied during 

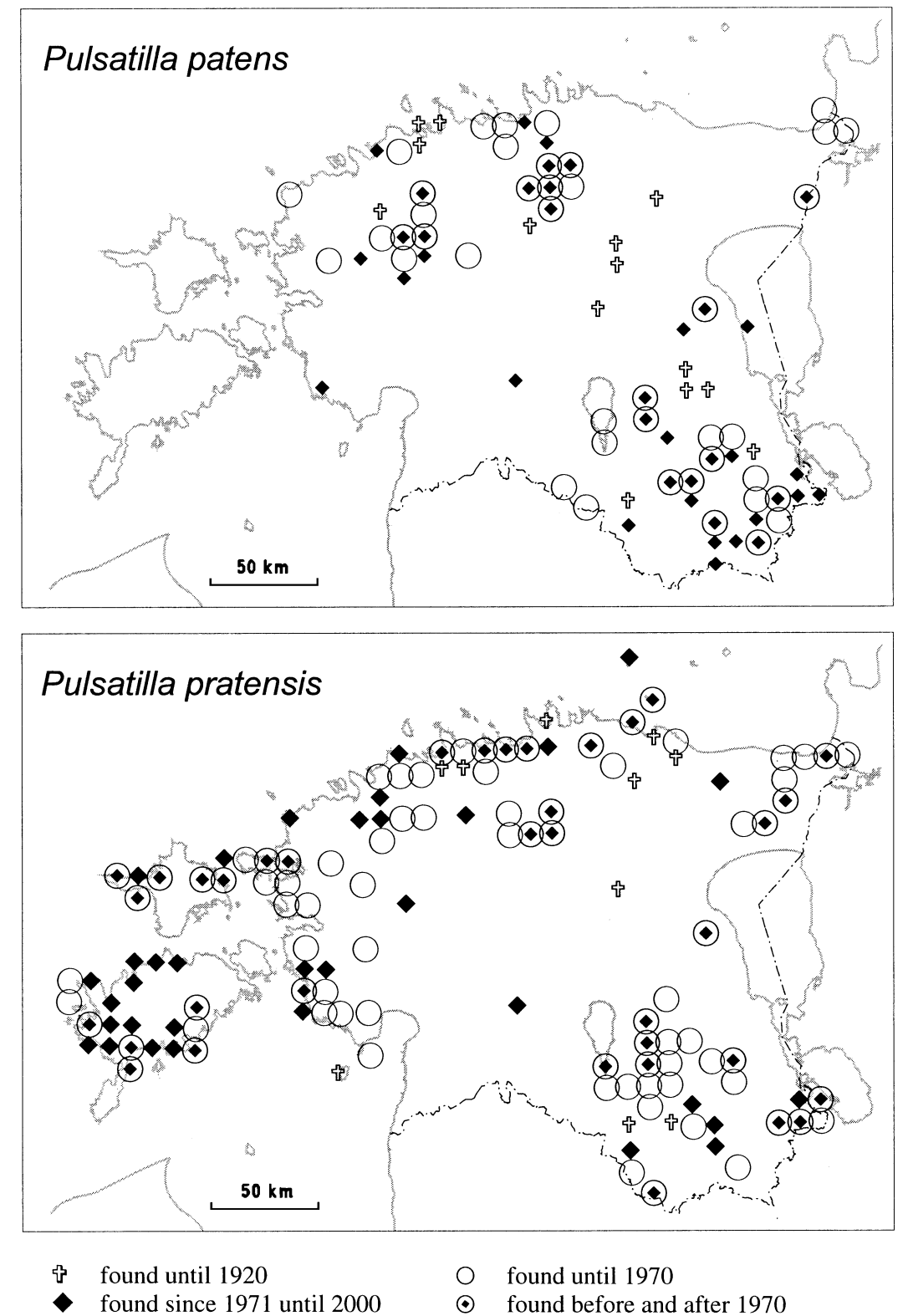

Fig. 1. Distribution of Pulsatilla patens and P. pratensis in Estonia.

the period from 1971 to 2000, 35 (almost 50\%) are "new sites". The same phenomenon is observable in the case of $P$. pratensis. Still, when comparing the last two periods, retreat on the Estonian mainland and expansion on Saaremaa Island can be observed. 


\section{Population size}

The (local) population sizes of both species were very variable (Appendix). Of the 29 populations of $P$. patens, 5 were of an order of magnitude (OM) of 10000 plants, 5 of OM of 1000, 13 of OM of 100, and 6 of OM of 10 plants. Of the 34 populations of $P$. pratensis, the corresponding numbers were $8,12,12$, and 2 . So, in general, populations are larger in the case of $P$. pratensis - almost $2 / 3$ of the populations, compared to $1 / 3$ for $P$. patens, are of a size of a thousand plants or more. In some places, like the western coast and islands, $P$. pratensis is distributed almost continuously over several kilometres.

\section{Habitat}

In Estonia, both P. patens and P. pratensis grow in various habitats, and their habitat preferences are at least to some extent overlapping, since there are several mixed populations (Appendix). The majority of populations of both species (21 of 29 for P. patens, 20 of 34 for P. pratensis) are found in pine (Pinus sylvestris) dominated boreal heath forests of Cladina or Calluna site type and in dry boreal forests of Vaccinium vitis-idaea site type, occasionally also in more humid Vaccinium myrtillus site type. Of alvar areas, P. patens is found more often in sparse forests of Arctostaphylos-alvar and Calamagrostis-alvar site types. $P$. pratensis prefers the more open areas of dry alvar grassland site type and dry boreal grasslands, and is abundant in coastal areas of grey dyne site type as well. Both species also grow in open anthropogenic habitats such as road and railroad edges, which are mown or burned. In other habitats too, human influence is frequently evident, including logging, grazing, excavations for sand, etc.

Pasqueflowers usually grow in open or half-open locations such as forest edges, clearings, and slopes of southern exposition, where the shrub layer is sparse, the herb layer is low, and graminoids are scarce or scattered. While populations or parts of populations of $P$. pratensis were found growing in open (16 sites) and half-open locations (20 sites) with similar frequency, then P.patens was considerably more frequent in half-open locations (23 sites) than in open ones (7 sites). Under closed canopy, $P$. patens was found in seven and $P$. pratensis in six locations.

\section{Soil conditions}

In various habitat types where the species grow, the substrates also vary. All main types of dry soils (soils without signs of gleization) in Estonia are represented (Reintam, 1995), including rendzinas, podzols, brown forest soils, and even sands and gravels in the coastal epilittoral zone (Table 1). The soils have a variable $\mathrm{pH}$, ranging from 5.1 to 8.4 for P. patens, and from 5.4 to 8.9 for $P$. pratensis. The soil nitrogen content varied considerably for both species, being as low as 0.01 and as high as $1.34 \%$, as did movable phosphorus (from 0.6 to 
Table 1. Soil properties of Pulsatilla patens (pat) or P. pratensis (prat) sites. Samples collected in 1999 and 2000. pH $\left(\mathrm{H}_{2} \mathrm{O}\right), \mathrm{N}$ (overall \%), $\mathrm{P}(\mathrm{mg} / 100 \mathrm{~g}$ soil), and $\mathrm{K}(\mathrm{mg} / 100 \mathrm{~g}$ soil) content in the upper $30 \mathrm{~cm}$ layer of the soil. Humus content of the (O) A horizon. See Appendix for population and habitat data

\begin{tabular}{|c|c|c|c|c|c|c|c|}
\hline $\begin{array}{l}\text { Site: soil type; thickness of } \\
\text { organic horizons }(\mathrm{cm}) \text {; texture }\end{array}$ & Species & Year & $\mathrm{pH}$ & $\mathrm{N}$ & $\mathrm{P}$ & K & Humus \\
\hline $\begin{array}{l}\text { Apuparra: podzol; O 2-4, } \\
\text { A 0-2; clay-sand }\end{array}$ & Pat & 2000 & 5.1 & 0.086 & 9.4 & 4.0 & 7.06 \\
\hline $\begin{array}{l}\text { Gorodenko: brown forest soil; } \\
\quad \text { O 2-5, A 20; sand-clay }\end{array}$ & Pat & 2000 & 5.7 & 0.077 & 4.3 & 3.5 & 3.26 \\
\hline $\begin{array}{l}\text { Lipstu: thin rendzina; } A \sim 5 \mathrm{~cm} \\
\text { over massive limestone }\end{array}$ & Pat & 2000 & 6.8 & 1.342 & 0.6 & 27.4 & 31.14 \\
\hline $\begin{array}{l}\text { Piusa: podzol; }(\mathrm{O}) \mathrm{A}<3 \text {; } \\
\quad \text { clay-sand }\end{array}$ & Pat/pra & 1999 & 8.4 & 0.050 & 1.7 & 6.6 & - \\
\hline $\begin{array}{l}\text { Soomaa: podzol; O 1-2, } \\
\text { A 10-15; clay-sand }\end{array}$ & Pat/pra & $\begin{array}{l}1999 / \\
2000\end{array}$ & $\begin{array}{l}7.7 / \\
5.4\end{array}$ & $\begin{array}{l}0.059 / \\
0.033\end{array}$ & $\begin{array}{c}10.1 / \\
6.1\end{array}$ & $\begin{array}{l}5.4 / \\
3.1\end{array}$ & $\begin{array}{l}-1 \\
2.14\end{array}$ \\
\hline $\begin{array}{l}\text { Pangodi: podzol; O 1-4, A 0-3; } \\
\quad \text { clay-sand }\end{array}$ & Pra & 1999 & 8.6 & 0.109 & 9.8 & 13.3 & - \\
\hline $\begin{array}{l}\text { Ramsi: coastal gravel covered } \\
\text { with sand }(10-70) ;(\mathrm{O}) \text { A } 0-3\end{array}$ & Pra & 2000 & 8.9 & 0.010 & 1.3 & 2.1 & - \\
\hline $\begin{array}{l}\text { Varbla: podzol; O 5, A 1-3; } \\
\text { clay-sand }\end{array}$ & Pra & 1999 & 7.2 & 0.057 & 4.1 & 6.1 & - \\
\hline
\end{tabular}

$10.1 \mathrm{mg} \mathrm{P} / \mathrm{mg}$ soil) and potassium (27.4 to $2.1 \mathrm{mg} \mathrm{K} / \mathrm{mg}$ soil). The high humus content measured in Apuparra (7.06\%) is attributable to earlier fires in the area. Rendzinas are characterized by an extremely high humus content $(26.5 \pm 5 \%$; Zobel, 1985) reflected also in the Lipstu site (31.14\%).

\section{DISCUSSION}

Despite the changes in the course of time, the overall distribution pattern for both Pulsatilla species, especially for P. patens, in Estonia remained more or less the same during the 20th century. Comparison of the distribution before and after 1970 shows that appearances and disappearances involved mainly neighbouring UTM quadrats. The "regionally static nature" of Pulsatilla species is well known. In Finland $P$. patens grows only in the region of South Häme, where it has existed since the last glaciation (Uotila, 1969, 1996). In England a closely related species 
- P. vulgaris - has appeared to be unable to colonize areas with abiotic conditions similar to those in its current habitats (Wells \& Barling, 1971).

Since the first half of the 20th century, the main agricultural activities have shifted from western to eastern Estonia (Mander \& Palang, 1999). Decline of P. pratensis on the Estonian mainland and its expansion on Saaremaa Island is probably associated with this change. While at the beginning of the 20th century $88 \%$ of the area of Saaremaa Island was in agricultural use, then in 1992 this proportion was only around 30\% (Mander \& Palang, 1999). However, the overgrowing of former open areas, remaining after the cessation of economic activities, is under way. The area of alvar grassland, which is characteristic of western islands and West Estonia as a whole, is rapidly decreasing. When two decades ago the area of alvar grassland was estimated at 16000 ha (Aug \& Kokk, 1983), then today it has declined considerably, making up only a third of this figure (Pärtel et al., 1999). Areas with permanently dry soil constitute about 3000 to 4000 ha at present (M. Pärtel, pers. comm.).

The buffering capacity of a species against changing environmental conditions involves efficient dispersal, both in space and time. For many temperate forest and grassland species, long individual life span is the trait enabling its spreading in time, since these species usually lack a persistent seed bank (Thompson et al., 1997; Baskin \& Baskin, 1998). Life span is also the main determinant of the speed of reaction to altering conditions - long-lived species react considerably slower (Eriksson, 1996).

Several current localities, especially for $P$. patens, consist of only a few plants in locations where the conditions could be assumed to have been more favourable a decade or two ago. Therefore, many "new" populations are quite likely "old" ones that have remained unnoticed in previous surveys, since their numbers had been severely reduced by unfavourable conditions. For the same reason we could assume that several "extinctions" are due to the use of inexact locality information when checking the old data, due to visiting the places at an unsuitable time (when leaves are not developed, or when the vegetation is already too dense for a population to be noticed), etc. When the populations have passed several severe bottlenecks, this should also be revealed in population genetic structure (Ellstrand \& Ellam, 1993); however, we have no data about this at the moment.

Vigorous populations are found in open or half-open locations with good light availability. An improvement of light conditions usually takes place as a result of some disturbance, such as fire, which removes the ground vegetation, but leaves rhizomes of pasqueflowers almost undamaged (Wildeman \& Steeves, 1982; Uotila, 1996). Available statistics about forest fires in Estonia dates back to 1921. The total area affected annually has been very variable, from 10.9 ha in 1977 to 4733 ha in 1933 (Alton, 2000), the latter constituting about $0.6 \%$ of the total forest area of that time (forest area according to Mander \& Palang, 1999). Considering that most fires occur in dry areas, preferred by pasqueflowers (suitable forest site types constitute around 14\% of Estonia's total forest area, according to Lõhmus, 1984), their impact could still be significant. Fires remove the moss layer. Vegetation descriptions made with an interval of 5 years (Kari- 
järve, East Estonia) showed that the populations of both species, but especially of $P$. patens, had diminished substantially. The only reason for this seems to be an increase in moss layer density.

Other disturbances of anthropogenic nature besides fires, such as logging, mowing, grazing, etc., also facilitate regeneration by seeds, which could be very unreliable in natural established vegetation. As the two Pulsatilla species have no persistent seed bank, regeneration depends not only on suitable conditions for establishment, but also on seed production at any particular locality at any moment of time. Widen \& Lindell (1995) reported great annual variation in seed production for $P$. pratensis. As seeds of both species usually disperse over short distances, establishment of new local populations or expansion of the existing ones is evidently dispersal-limited. The species are hence quite disturbancedependent, and they should therefore be classified as apophytes (Enari, 1944; Uotila, 1969, 1996), rather than hemeradiophores (Kukk, 1999).

In respect of soil nutrient status and $\mathrm{pH}$, both species show a rather wide amplitude of tolerance. In general, $P$. pratensis seems to prefer sites with more neutral soils (cf. also Ellenberg et al., 1991). Higher $\mathrm{pH}$ values are mainly attributable to limestone content in the soil profile, but in coastal zones (see Ramsi site in Table 1) also to the influence of seawater, which has a $\mathrm{pH}$ around 9 (Reeve \& Barnes, 1994).

In respect of moisture availability, $P$. patens has a narrower amplitude of tolerance (Uotila, 1969) and prefers more humid sites (cf. also Ellenberg et al., 1991) than P. pratensis. An adverse impact of low moisture availability was observed (I. Pilt \& M. Öpik, pers. comm.) in a mixed population (railroad edge near Piusa, South Estonia) that suffered from severe drought in late summer 1999. Leaves of P. patens withered totally; those of P. pratensis showed strong signs of drought stress, but mostly survived.

On the basis of the distribution of the site types where soil conditions are suitable for Pulsatilla species, we estimated that around $10 \%$ of the territory of Estonia should be potentially habitable for both species. These potentially suitable habitats may become even more favourable, as mentioned above, when appropriate light conditions are provided. There are several threatening factors that may cause extremely severe population reduction and/or eliminate regeneration possibilities in the close proximity of established plants. Decreases in the distribution are probably caused by fragmentation of habitats and by peculiarities in reproductive systems of plants (Kull et al., 2002). Forest clear-cutting, whose volume has greatly increased in Estonia during the last years, is definitely the main factor destroying the habitats of the Pulsatilla species. Despite the fact that cutting improves lighting, the current practice of clear-cutting has many adverse impacts on the pasqueflowers. Heavy machines destroy rhizomes, and soil disturbance promotes the invasion of ruderal species or light-demanding grasses, forming a dense vegetation cover, under which the establishment of new Pulsatilla seedlings is impossible. Frequently logging debris, windfallen trees, etc. are left on logging sites. This can promote species biodiversity (fungi, mosses, etc.), but also results in the eutrofication of the site and the following 
establishment of a dense vegetation cover. Overgrowing of formerly open grassland areas is also harmful to pasqueflowers, especially $P$. pratensis.

Destruction of habitats and established populations due to the expansion of human settlement does not endanger the present-day populations of P. patens, as this species has already disappeared from the vicinity of towns. P. pratensis, on the other hand, is frequently also found in forest-park suburbs. Although $P$. patens is protected by the law, its eye-catching flowers are often picked. The influence of this as a threatening factor may still be quite low. Protection efforts must therefore concentrate on the avoidance of overgrowing, as well as the adoption of sustainable logging practices in the species' current habitats.

\section{ACKNOWLEDGEMENTS}

The authors thank their colleagues, especially Ene Hurt and Maarja Öpik, for help in fieldwork. Ene Hurt also designed the maps. Milvi Purgas analysed the soil samples. Ilmar Part revised the English. The work was supported by the Estonian Science Foundation (ESF grants No. 4468 and No. 3574).

APPENDIX

\section{HABITAT DATA ABOUT P. PATENS AND P. PRATENSIS POPULATIONS IN ESTONIA, CHECKED 1995-2000}

Region denotes the placement of a population, based on the UTM grid system, and is referred to by two letter symbols (Fig. 2). Mixed populations are marked with an asterisk.

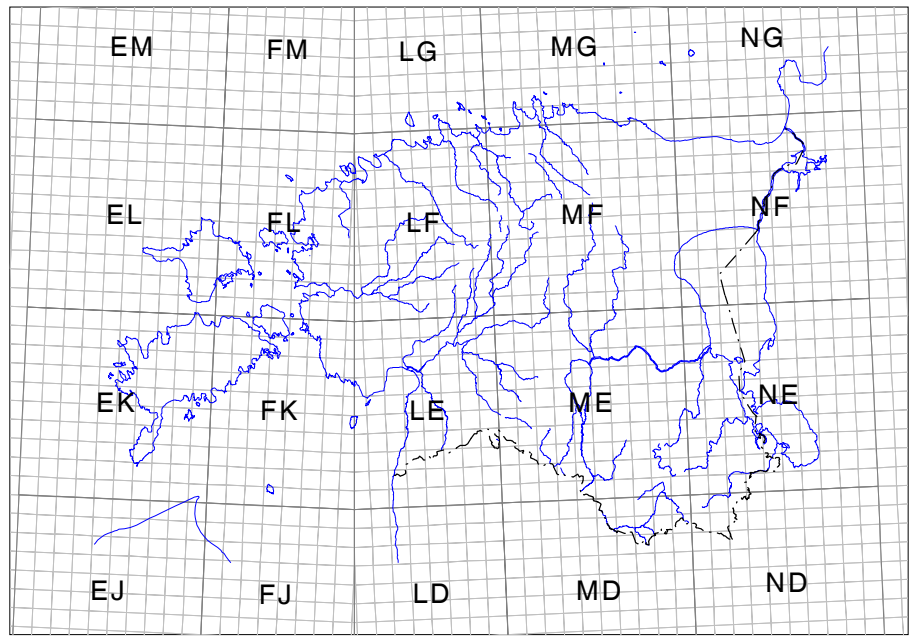

Fig. 2. UTM grid notation. 
Pulsatilla patens

\begin{tabular}{|c|c|c|c|c|}
\hline Population & $\begin{array}{l}\text { Re- } \\
\text { gion }\end{array}$ & Pop. size & Light & Growth site type group/site type \\
\hline Abru & $\mathrm{LF}$ & 10000 & Half-open/open & $\begin{array}{l}\text { Alvar forests and shrublands/Arctostaphylos- } \\
\text { alvar }\end{array}$ \\
\hline Apuparra & MF & 1000 & Half-open/closed & Boreal heath forest/Calluna \\
\hline Elva & $\mathrm{ME}$ & 100 & Half-open & Dry boreal forest/Vaccinium vitis-idaea \\
\hline Gorodenko & $\mathrm{NF}$ & 1000 & Half-open & Dry boreal forest/Vaccinium vitis-idaea \\
\hline Harakajärve & MF & 10000 & $\begin{array}{l}\text { Half- } \\
\text { open/closed/open }\end{array}$ & Boreal heath forest/Calluna \\
\hline Hummuli & ME & 10 & Half-open & Dry boreal forest/Vaccinium vitis-idaea \\
\hline Jussi lakes & MF & 100 & Half-open & Boreal heath forest/Calluna \\
\hline Kaiu & MF & 10 & Closed & Boreal heath forest/Cladina \\
\hline Karijärve* & ME & 10 & Half-open & Dry boreal forest/Vaccinium myrtillus \\
\hline Koonukõrve & MF & 100 & Open & Dry boreal heath grassland \\
\hline Lindora & $\mathrm{NE}$ & 10 & Half-open & Dry boreal forest/Vaccinium vitis-idaea \\
\hline Lipstu & LF & 10000 & Half-open/open & $\begin{array}{l}\text { Alvar forests and shrublands/Arctostaphylos- } \\
\text { alvar }\end{array}$ \\
\hline Mustametsa & ME & 10 & Closed & Dry boreal forest/Vaccinium vitis-idaea \\
\hline Osula* & ME & 100 & Half-open & Yard \\
\hline Palojärve & ME & 1000 & Half-open & Road edge \\
\hline Piusa* & $\mathrm{NE}$ & 10000 & Open & Railroad edge \\
\hline Punamäe & MF & 100 & Closed/half-open & Dry boreal forest/Vaccinium vitis-idaea \\
\hline Rootsiküla & $\mathrm{NE}$ & 10 & Open & Boreal heath forest/Calluna \\
\hline Rutka & MF & 100 & Half-open & $\begin{array}{l}\text { Alvar forests and shrublands/Calamagrostis- } \\
\text { alvar }\end{array}$ \\
\hline Soomaa* & ME & 100 & Half-open & Boreal heath forest/Calluna \\
\hline Türisalu & $\mathrm{LF}$ & 100 & Half-open & Dry boreal forest/Vaccinium vitis-idaea \\
\hline Umbsaare & $\mathrm{NE}$ & 100 & Closed/half-open & Boreal heath forest/Calluna \\
\hline Vana-Nursi & ME & 10000 & Half-open/open & Boreal heath forest/Calluna \\
\hline Vargamäe Hills & MF & 100 & Half-open & Dry boreal forest/Vaccinium vitis-idaea \\
\hline Vastseliina & $\mathrm{NE}$ & 1000 & Half-open/closed & Dry boreal forest/Vaccinium vitis-idaea \\
\hline Verijärv & $\mathrm{NE}$ & 100 & Half-open & Dry boreal forest/Vaccinium myrtillus \\
\hline Veski & $\mathrm{NE}$ & 100 & Half-open & Boreal heath forest/Calluna \\
\hline Vulbi & MF & 1000 & Half-open & $\begin{array}{l}\text { Alvar forests and shrublands/Calamagrostis- } \\
\text { alvar }\end{array}$ \\
\hline Värska* & $\mathrm{NE}$ & 100 & Half-open & Boreal heath forest/Calluna, Cladina \\
\hline
\end{tabular}

Pulsatilla pratensis

\begin{tabular}{|c|c|c|c|c|}
\hline Population & $\begin{array}{l}\text { Re- } \\
\text { gion }\end{array}$ & Pop. size & Light & Growth site type group/site type \\
\hline Andineeme & MF & 1000 & Half-open & Boreal heath forest/Calluna \\
\hline $\begin{array}{l}\text { Andineeme- } \\
\text { Muuksi }\end{array}$ & $\mathrm{MF}$ & 1000 & Closed & Dry boreal forest/Vaccinium vitis-idaea \\
\hline Asema & $\mathrm{ME}$ & 1000 & Open & Dry boreal forest/Vaccinium vitis-idaea \\
\hline Einby & FL & 1000 & Half-open/c & Road edge \\
\hline
\end{tabular}




\begin{tabular}{|c|c|c|c|c|}
\hline Population & $\begin{array}{l}\mathrm{Re}- \\
\text { gion }\end{array}$ & Pop. size & Light & Growth site type group/site type \\
\hline Ennu, Vätta & EK & 1000 & Open & Dry alvar grassland \\
\hline Harilaid & EK & 10000 & Open & Dry alvar grassland \\
\hline Jõuga & NF & 100 & Open & Dry boreal grassland \\
\hline Järve & EK & 100 & Open & Gray dyne site type \\
\hline Kaberla & MF & 100 & Half-open/closed & Dry boreal forest/Vaccinium vitis-idaea \\
\hline Karepa & MG & 10000 & Half-open & Boreal heath forest/Calluna; gray dyne site type \\
\hline Karijärve* & ME & 1000 & Half-open & Dry boreal forest/Vaccinium myrtillus \\
\hline Kutniku & MF & 100 & Half-open/closed & Dry boreal forest/Vaccinium vitis-idaea \\
\hline Kärgula & ME & 100 & Open & Old opencast \\
\hline Matsirand & FK & 1000 & Half-open & Boreal heath forest/Calluna \\
\hline Mustametsa & MF & 100 & Half-open & Dry boreal forest/Vaccinium vitis-idaea \\
\hline Mäepea & EK & 100 & Open & Arctostaphylos-alvar \\
\hline Narva-Jõesuu & NF & 100 & Half-open & Boreal heath forest/Calluna; gray dyne site type \\
\hline Osula* & ME & 10000 & Open/half-open & Yard \\
\hline Palumäe & ME & 10000 & Open/half-open & $\begin{array}{l}\text { Inland sandy plain site type; dry boreal } \\
\text { forest/Vaccinium vitis-idaea }\end{array}$ \\
\hline Piusa* & $\mathrm{NE}$ & 10000 & Open & Railroad edge \\
\hline Pudisoo-Kolga & MF & 100 & Closed & Dry boreal forest/Vaccinium vitis-idaea \\
\hline Ramsi & FL & 10000 & Open & Gray dyne site type \\
\hline Riisipere & $\mathrm{LF}$ & 10000 & $\begin{array}{l}\text { Half- } \\
\text { open/closed }\end{array}$ & Dry boreal forest/Vaccinium vitis-idaea \\
\hline Ristna & EL & 1000 & Half-open & Boreal heath forest/Calluna \\
\hline Soomaa* & ME & 1000 & Half-open & Boreal heath forest/Calluna \\
\hline Suur Umbjärv & ME & 1000 & Half-open & Dry boreal forest/Vaccinium vitis-idaea \\
\hline Tammiku & $\mathrm{LF}$ & 100 & Half-open & Alvar forests and shrublands/Calamagrostis-alvar \\
\hline $\begin{array}{l}\text { Vaindloo, } \\
\text { Uhtju }\end{array}$ & MG & 100 & Open & Dry boreal grassland \\
\hline Varbla & FK & 1000 & Open/half-open & Boreal heath forest/Calluna \\
\hline Varesmetsa I & NF & 100 & Half-open & Dry boreal forest/Vaccinium vitis-idaea \\
\hline Varesmetsa II & NF & 10 & Half-open & Dry boreal forest/Vaccinium vitis-idaea \\
\hline Vasalemma & $\mathrm{LF}$ & 10 & Open & Dry alvar grassland \\
\hline Vatla & FK & 10000 & Open & Dry alvar grassland \\
\hline Värska* & $\mathrm{NE}$ & 1000 & Open/half-open & Boreal heath forest/Cladina \\
\hline
\end{tabular}

\section{REFERENCES}

Alton, H. 2000. Metsapõlemised Eestis. Eesti Loodus, 7/8, 284-286.

Anon. 1992. Truete arter i Norge. Norwegian red list. DN-rapport 1992 - 6. Directorate for Nature Management, Trondheim.

Aug, H. \& Kokk, R. 1983. Eesti NSV looduslike rohumaade levik ja saagikus. ENSV ATK Informatsiooni ja Juurutamise Valitsus, Tallinn.

Baskin, C. C. \& Baskin, J. M. 1998. Seeds. Ecology, Biogeography, and Evolution of Dormancy and Germination. Academic Press, San Diego. 
Eesti NSV Floora I-XI. 1953-1984. Valgus, Tallinn.

Ellenberg, H., Weber, H. E., Düll, R., Wirth, V., Werner, W. \& Paulisen, D. 1991. Zeigerwerte von Pflanzen in Mitteleuropa. Scri. Geobot., 18, 12-48.

Ellstrand, N. C. \& Ellam, D. R. 1993. Population genetic consequences of small population size: implications for plant conservation. Annu. Rev. Ecol. Syst., 24, 217-242.

Enari, L. 1944. Kultuuri mõju Eesti floorale. Doctoral thesis. TÜ matemaatika-loodusteaduskond, Tartu. [BÖI]

Eriksson, O. 1996. Population ecology and conservation - some theoretical considerations with examples from the Nordic flora. Acta Univ. Ups. Symb. Bot. Ups., 31, 159-167.

Eriksson, O. \& Jakobsson, A. 1998. Abundance, distribution and life histories of grassland plants: a comparative study of 81 species. J. Ecol., 86, 922-933.

Hegi, G. 1965-1974. Illustrierte Flora von Mitteleuropa. Pteridophyta, Spermatophyta. Band III Angiospermae, Dicotyledones 1. Verlag Paul Parey, Berlin, Hamburg.

Hodgson, J. G. 1986. Commonness and rarity in plants with special reference to the Sheffield flora. Part II. The relative importance of climate, soils and land use. Biol. Conserv., 36, 253-274.

Hulten, E. \& Fries, M. 1986. Atlas of North European Vascular Plants. North of the Tropic of Cancer. Koeltz Scientific Books, Köningsberg.

Ingelög, T., Andersson, R. \& Tjernberg, M. (eds.) 1993. Red Data Book of the Baltic Region. Part 1. Lists of Threatened Vascular Plants and Vertebrates. Swedish Threatened Species unit, Uppsala in co-operation with the Institute of Biology, Riga, Södertälje.

Jalas, J. \& Suominen, J. (eds.) 1989. Atlas Florae Europaeae. Distribution of Vascular Plants in Europe 8. Nymphaeaceae to Ranunculaceae. Committee for Mapping the Flora of Europe, Societas Biologica Fennica, Vanamo, Helsinki.

Klecak, G., Wohlgemuth, T. \& Schneller, J. J. 1997. Regionale Florenwerke und ihre Bedeutung für die Rekonstruktion räumlicher und zeitlicher Dynamik seltener Pflanzenarten. Bot. Helv., 107, 239-262.

Kotiranta, H., Uotila, P., Sulkava, S. \& Peltonen, S.-L. (eds.) 1998. Red Data Book of East Fennoscandia. Ministry of the Environment, Finnish Environment Institute, and Botanical Museum, Finnish Museum of Natural History, Helsinki.

Kukk, T. 1999. Eesti taimestik. Teaduste Akadeemia Kirjastus, Tartu-Tallinn.

Kull, T., Kukk, T., Leht, M., Krall, H., Kukk, Ü., Kull, K. \& Kuusk, V. 2002. Distribution trends of rare vascular plant species in Estonia. Biodiv. Conserv., 11, 171-196.

Laasimer, L. 1965. Eesti NSV taimkate. Valgus, Tallinn.

Lilleleht, V. (comp.) 1998. Eesti Punane Raamat. Ohustatud seened, taimed ja loomad. ETA Looduskaitse Komisjon, Tartu.

Lõhmus, E. 1984. Eesti metsakasvukohatü̈̈bid. Eesti NSV Agrotööstuskoondise Info- ja Juurutusvalitsus, Tartu.

Mander, Ü. \& Palang, H. 1994. Changes in landscape structure in Estonia during the Soviet period. GeoJournal, 33, 45-54.

Mander, Ü. \& Palang, H. 1999. Landscape changes in Estonia: reasons, processes, consequences. In Land-use Changes and Their Environmental Impact in Rural Areas in Europe (Krönert, R., Baudry, J., Bowler, I. R. \& Reenberg, A., eds.), pp. 165-187. MAB Series 24. The Parthenon Publishing Group, Paris.

Mander, Ü., Palang, H. \& Tammiksaar, E. 1994. Landscape changes in Estonia during the 20th century. In Analysis of Landscape Dynamics - Driving Factors Related to Different Scales (Krönert, R., ed.), pp. 73-97. Proc. 4th Seminar of EUROMAB Network on Land-use Changes in Europe and Their Impact on Environment - Comparisons of Landscape Dynamics in European Rural Areas. Bad Lauchstädt, Germany, 27 September-1 October 1993.

Moore, P. D. \& Chapman, S. B. (eds.) 1986. Methods in Plant Ecology. Blackwell Scientific Publications, Oxford. 
Mücher, C. A., Steinnocher, K. T., Kressler, F. P. \& Heunks, C. 2000. Land cover characterization and change detection for environmental monitoring of pan-Europe. J. Remote Sens., 21, $1158-1181$

Paal, J. 1997. Eesti taimkatte kasvukohatü̈̈pide klassifikatsioon. KKM Info- ja Tehnokeskus, Tallinn.

Pärtel, M., Kalamees, R., Zobel, M. \& Rosen, E. 1999. Alvar grasslands in Estonia: variation in species composition and community structure. J. Veget. Sci., 10, 561-570.

Reeve, R. N. \& Barnes, J. D. 1994. Environmental Analysis. John Wiley \& Sons, Chichester etc.

Reintam, L. 1986. Muldade määraja. Eesti Põllumajanduse Akadeemia, Tartu.

Reintam, L. 1995. Soils in Estonia. In Soil and Fertilization (Kuldkepp, P., ed.), pp. 122-131. Estonian Agricultural University, Tartu.

Rysina, G. P. 1981. On the biology of Pulsatilla patens (L.) Mill. in the environs of Moscow. Bull. Moscowian Nat. Soc., 86, 129-134.

Thompson, K., Bakker, J. P. \& Bekker, R. M. 1997. Soil Seed Banks of North-West Europe: Methodology, Density and Longevity. Cambridge University Press.

Torvik, S. E., Borgen, L. \& Berg, R. Y. 1998. Aspects of reproduction in Pulsatilla pratensis in Norway. Nord. J. Bot., 18, 385-391.

Uotila, P. 1969. Ecology and area of Pulsatilla patens (L.) Mill. in Finland. Ann. Bot. Fenn., 6, 105-111.

Uotila, P. 1996. Decline of Anemone patens (Ranunculaceae) in Finland. Acta Univ. Ups. Symb. Bot. Ups., 31, 205-210.

Wells, T. C. E. \& Barling, D. M. 1971. Biological flora of the British Isles. Pulsatilla vulgaris Mill. (Anemone pulsatilla L.). J. Ecol., 59, 275-292.

Widen, B. \& Lindell, T. 1995. Flowering and fruiting phenology in two perennial herbs, Anemone pulsatilla and A. pratensis (Ranunculaceae). Symb. Bot. Upps., 31, 145-158.

Wildeman, A. G. \& Steeves, T. A. 1982. The morphology and growth cycle of Anemone patens. Can. J. Bot., 60, 1126-1137.

Zobel, M. 1985. Ecology of alvar soils in the coastal zone of Baltic Sea. Soviet J. Soil Sci., 12, 14-23 (in Russian).

\section{Pulsatilla patens ja Pulsatilla pratensis Eestis: levik ja ökoloogia}

\section{Indrek Pilt ja Ülle Kukk}

Palu-karukella (Pulsatilla patens) ja aas-karukella (Pulsatilla pratensis) levik Eestis on 20. sajandi jooksul olnud küllaltki stabiilne, hoolimata suurtest maakasutuse muutustest. 29 palu-karukella ja 34 aas-karukella populatsiooni ning nende kasvukohtade analüüsi alusel võiks ligikaudu kümnendik Eesti territooriumist sobida nimetatud liikide kasvuks. Mõlemad liigid eelistavad valgusrikkaid kasvukohti ja on soodustatud mõningasest inimtegevuse mõjust, nagu põlengud, metsaraie vms. Taimede pikk eluiga pärsib teataval määral kasvukohtade kinnikasvamise halvendavat mõju. Suurim ohuallikas karukellade populatsioonidele on praegusel ajal kasutatav metsaraie viis, mille tõttu moodustub tihe rohttaimkate ja halvenevad valgustingimused. 